\title{
Perceived Importance of English and Its Connection to Learning Motivation and Foreign Language Anxiety
}

\author{
Mojca Žefran \\ Faculty of Education, University of Primorska, Slovenia \\ mojca.zefran@pef.upr.si
}

\begin{abstract}
The paper focuses on the students' perception of the role of English as a foreign language and the correlation between the perceived importance of English to students' motivation for learning English and the levels of foreign language anxiety. The first part examines the theoretical aspects of foreign language learning motivation and foreign language anxiety. The second part presents the results of a study which was part of a larger-scale research carried out among 673 students and six teachers. A mixed methods approach was used to analyse quantitative and qualitative data. The results suggest that students perceptions of English have a considerable effect on their motivation and foreign language anxiety. As the study revealed, the perceived importance of the English language can be a cause of high motivation for learning English, but also one of the possible sources of foreign language anxiety among students. Keywords: perceived importance of English, foreign language learning motivation, foreign language anxiety
\end{abstract}

\section{Introduction}

In today's society, an individual is required to have a wide repertoire of competences and mastering a foreign language is undoubtedly one of them. One of the primary objectives of the EU language policy is that every European citizen should master two other languages in addition to their mother tongue (European parliament 2015). The most important foreign language is undoubtedly English, which has become the dominant global language (Pennycook 1999; Ryan 2006). According to Key data on teaching languages at school in Europe (Eurydice 2017), the number of pupils learning at least one foreign language in Slovenian primary schools rose by at least $25 \%$ between the years 2005 and 2014, the number of students learning at least two foreign languages in lower secondary education increased by more than $30 \%$, whereas the number of students learning at least two foreign languages in upper secondary education remained relatively stable as it was already higher than $95 \%$. A higher proportion of pupils and students learning one or more foreign languages is partly due to the changes in the education system, such 
as the implementation of compulsory foreign language learning in the 2nd grade of primary school.

The Eurydice data also shows that despite the wide variety of languages spoken in the EU, the most studied foreign language in Europe is English (Eurydice 2017). The area of English as a lingua franca has become a discipline in its own right which has been investigated from multiple perspectives ( $\mathrm{Bra}$ tož and Žefran 2012; Crystal 2012; Čeh 2012; House 2003; Jenkins 2007; Kachru 1992; Seidlhofer 2005) and the Common European Framework for Languages (CEFR) stresses the value of learning English. Given the dominant status of English in the world as well as in Slovenia, it is clear that our society places great emphasis on the importance of learning English as a foreign language. What is more, mastery of the English language is often taken for granted leading to high expectations with respect to English language proficiency. As a result, language learners are often under pressure to perform in English which may lead to foreign language anxiety, fear from failure and negative attitudes towards language learning. Therefore, the aim of our research was to investigate how students perceive the role of English as a foreign language and the correlation between the perceived importance of English to students' motivation for learning English and the levels of foreign language anxiety.

\section{Theoretical Background}

Our research focuses on the area of individual differences in language learning which, according to Dörnyei and Ryan $(2015,2)$, involve all the characteristics in which individuals may differ from each other. When considering individual differences relevant in the field of language learning, the majority of authors in the field focus on relatively stable dimensions that fulfil two criteria: are applicable to everyone and discriminate among individuals. Research on individual differences in language learning began with the study of language aptitude - first in the 1930 s with Symonds' Foreign language prognosis test and later in the 1950 s and 1960 s with Carroll and Sapon's Modern Language Aptitude Test (1959). At that time researchers also started focusing on motivation; the most prominent authors of the time being Robert Gardner and Wallace Lambert who later presented a theory that identified several social psychological factors affecting foreign language acquisition (Gardner and Lambert 1972). This was the foundation of Gardner's socio-educational model of second language acquisition (Gardner 1985), which incorporates covers several learner characteristics influencing foreign language acquisition, such as intelligence, language aptitude and language learning strategies. In addition to these characteristics, Gardner's model incorporates mo- 
tivation, language attitudes and language anxiety, which have lately been researched and studied extensively by several authors.

\section{Motivation}

Foreign language learning motivation is undoubtedly one of the main factors affecting foreign language acquisition. As Dörnyei and Ryan $(2015,72)$ put it, without sufficient motivation even individuals with exceptional abilities cannot achieve long-term goals, whereas high levels of motivation can compensate for lack of language aptitude or poor learning conditions. Considerable attention has been dedicated to the topic of FL motivation in the past few decades (see Apple, DaSilva, and Fellner 2013, Csizer and Magid 2014; Dörnyei, Maclntyre and, Henry 2015; Dörnyei and Schmidt 2001; Dörnyei and Ushioda 2009; Lasagabaster, Doiz, and Sierra 2014; Murray, Gao, and Lamb 2011; Ushioda 2013). One of the reasons why motivation is such an appealing concept for researchers may be in the fact that it is a complex and dynamic concept. As argued by Gardner (2006), motivation as a concept cannot be measured with a single scale but in order to measure it, one can describe the characteristics of a motivated individual. According to Gregersen and MacIntyre (2014) definitions of motivation change depending on the theoretical approach of the researcher. Regardless of the differences between different definitions, various motivation models draw very similar conclusions and the theories, most importantly, do not contradict each other but rather focus on different concepts and processes (Gardner and Clément 1990).

Instead of examining the theoretical nuances of different models, Gregersen and Maclntyre (2014, 108-14), similarly to Dörnyei and Ryan (2015, 73-4), look into the history of FL research which can be divided into three periods which examine the concept from different perspectives: 'the social psychological period,' 'the cognitive-situated period' and 'the process-oriented period.' The first period of FL motivation research (the social psychological period) began in 1959 with Robert Gardner as the leading author of the time. However, Gardner was not the only researcher looking into motivation. Several other theories and models were developed: Schumann's acculturation theory (Schumann 1978; 1986), Clément's social context model (Clément 1980) and intergroup model by Giles and Byrne (1982). In the 1990s, we then witnessed 'the cognitive-situated period', which was the result of a considerable conceptual gap in motivation studies between the fields of foreign language acquisition and educational psychology. Authors tried to move away from social psychology towards the cognitive theories originally developed in 'non-L2-specific research,' for example Deci and Ryan's (1985; 2009) 
self-determination theory. And finally, following the cognitive-situated period, there is 'the process-oriented period' or as Dörnyei and Ryan (2015) also call it 'the socio-dynamic period,' which understands motivation as a dynamic factor rather than a static characteristic of an individual. Research in this period focuses on changes in motivation, particularly resulting from the interaction between individuals and contexts also taking into account the concept of temporal variation. Some of the theories developed in recent years are the Process Model by Dörnyei and Ottó (1998), the person-in-context relational view by Ushioda (2009), the 'L2 motivational self' system (Dörnyei 2005), and the complex dynamics systems perspectives (Ellis in Larsen-Freeman 2006; Dörnyei 2009).

\section{Foreign Language Anxiety}

According to Scovel $(1991,18)$ 'anxiety is a psychological construct, commonly described by psychologists as a state of apprehension, a vague fear that is only indirectly associated with an object.' Psychologists differentiate between two types of anxiety: trait anxiety which refers to a personality trait and a relatively stable tendency to experience anxiety in various situations; and state anxiety which represents temporary unpleasant emotional arousal related to specific situations. Horwitz (2001) adds another category of anxiety, called situation-specific anxiety which refers to anxiety caused by specific types of situations or events, such as the experience of learning a foreign language in the classroom. Although it can often be related to trait anxiety, research has shown that foreign language anxiety is a distinct construct that needs to be studied independently (Horwitz, Horwitz, and Cope 1986). Several researchers have focused on foreign language anxiety (Maclntyre and Gardner 1991) and its relation to foreign language achievement (Horwitz 2001; Matsuda and Gobel 2004; Mihaljević Djigunović 2012; Verma 2008; Vytal et al. 2012; Žefran and Cencič 2013). Their results have indicated a significant correlation between high levels of foreign language anxiety and poor foreign language achievement.

One of the most notable instruments for measuring foreign language anxiety is the thirty-three item Foreign Language Classroom Anxiety Scale (FCLAS) developed by Horwitz, Horwitz, and Cope (1986).

Foreign language anxiety can stem from a variety of different sources. Horwitz, Horwitz, and Cope (1986) suggest communication apprehension, fear from negative evaluation and test anxiety as the main sources. Similar conclusions have been drawn by Price (1991), whose research has shown a correlation between foreign language anxiety and perceived language aptitude, 
certain personality traits, such as perfectionism and fear from public speaking, and certain situations, e.g. speaking in front of peers (being afraid of ridicule). Young (1991) also added learner and teacher beliefs about language learning and teaching, especially if the students' beliefs collide with those of their instructors or with the reality of language learning. As other possible sources of foreign language anxiety Young (1991) cites instructor-learner interactions, classroom procedures, and language testing. Some researchers (Gregersen 2003; Young 1991) have found that error correction, if not handled in learner-friendly ways, can also be a significant source of anxiety. Gregersen and Maclntyre (2014) maintain that the relationship between errors and anxiety is almost a vicious circle: the more errors learners make the more anxious they become and anxiety then causes them to make even more errors, and the learners become less willing to participate in an attempt to protect their social image.

It has been shown time and again that foreign language anxiety negatively affects language learning and acquisition (Horwitz 2001; Maclntyre and Gardner 1991; Vytal et al. 2012). Gregersen and Maclntyre $(2014,6)$ note that 'foreign language classroom anxiety results in a litany of specific manifestations that work together to debilitate learners' progress' and go on to suggest various symptoms of foreign language anxiety that fall into four categories: physical (increased heartbeat, tension, trembling, less eye contact with the teacher, rigid posture), emotional/affective (fear of teacher correction, insecurity about speaking, worry about being left behind in class, feelings of incompetence when comparing oneself with others, embarrassment in volunteering responses), cognitive/linguistic (inability to distinguish sounds and structures, forgetting linguistic information one has learnt, over-studying with no significant gains), and interactional/social (less classroom participation, initi-

ating and participating in fewer conversations, speaking for shorter periods of time, rarely interrupting others, avoiding activities in class). Being aware of these manifestations can be of great value for teachers when trying to detect anxious learners in the classroom.

\section{Study Aims}

The research presented in this paper focused particularly on the nature of the connection between students' perceptions of the importance of English and their motivation for learning English and foreign language anxiety.

The aims of this study were:

- to identify students' perceptions of the importance of English, 
- to determine the connection between students' perceptions of English and their levels of foreign language anxiety,

- to determine the connection between students' perceptions of English and their levels of motivation for learning English.

\section{Sample}

This study was part of a larger-scale research carried out among 673 first-year students of the university of Primorska. The sample was composed of $82.9 \%$ female and $17.1 \%$ male students. In the qualitative part of the research the two focus groups each consisted of five students from the same sample: four female and one male. The interviews were carried out among three primary school teachers and three secondary school teachers. The first primary school teacher was female, an English teacher who has been teaching English in primary school for 10 years. The second interviewee was female, a primary school teacher with English. She has been a primary school teacher for 17 years and has been teaching English in primary school for the past 13 years. The third interviewee was male, a teacher of English and German with 16 years of teaching experience. For the first year he taught German in primary school and has been teaching English and partly German in primary school for 15 years. During that time, he also taught in secondary school. All three secondary school teachers of English were female. The first one has been teaching English in secondary school for 15 years, most of that time also in the last three years of primary school. The second teacher has 25 years of teaching experience in secondary school. The last interviewee has 19 years of teaching experience; the first three years she taught in a language school and has been teaching English in secondary school for 16 years.

\section{Methodology}

In our research a mixed methods approach was used, combining both quantitative and qualitative data in order to ensure a greater degree of understanding of the connection between the concepts.

The quantitative part of the research was carried out with the help of a questionnaire partly based on Gardner's AMTB (Gardner 2004) and Horwitz's FLCAS (Horwitz 2001). The data were analysed using SPSS (Statistical Package for the Social Sciences). The validity and the reliability of the instrument were confirmed in a previous study (Žefran and Cencič 2013; Žefran 2017), which indicated that the instrument is fairly reliable.

In the qualitative part of the research two focus groups of ten students, five in each group were interviewed, and interviews with three primary school 
teachers of English and three secondary school teachers of English were carried out. Focus group interviews were used as the method provides participants the opportunity to add further information to others' statements and facilitates spontaneous and informal discussions about the participants' experiences and perceptions. The first focus groups interview lasted one hour and 26 minutes and was facilitated by a fellow researcher as the author of this paper personally knew the participants and wanted to avoid the possible influence on the outcomes of the discussion. The second focus group interview was carried out by the author herself and lasted 55 minutes. The interviews with the teachers were carried out by the author of this study and all lasted between 30 minutes and one hour. Focus group discussions and the interviews were audio recorded and later transcribed. Participants' names were changed to ensure anonymity.

\section{Results and Discussion}

Before discussing the results of the study, we need to mention a significant finding we had not foreseen prior to our research: when investigating motivation for learning English, we should differentiate between two types of motivation, motivation for learning the language in informal vs. formal (i.e. classroom) settings. The two notions proved to be very distinct with students exhibiting high levels of motivation for learning the language but significantly lower levels of motivation and negative attitudes towards learning English in the classroom with 78.1 per cent of the students showing negative attitudes, 17.1 per cent showing neutral attitudes and only 4.8 per cent showing positive attitudes towards learning English in the classroom (Žefran 2017).

Results indicate an extremely high percentage of respondents exhibiting high (49.4 per cent) and very high motivation (48.2 per cent) for learning English with only 2.4 per cent reporting low levels of motivation (Žefran 2017).

We expected such results as similar findings have already been laid out by Juriševič and Pižorn (2013) who investigated motivation for learning a foreign language among primary school pupils but we believed that the reasons for such high levels of motivation should be looked for outside classroom settings, in the perceived role and status of the English language in the eyes of the students. The results from the interviews with the teachers as well as in the focus groups confirmed our prediction. A primary school teacher of English reported that learners' motivation stems from the perceived importance of English among her learners:

In my experience, English has become one of the main languages of the 
young people's free time and it suddenly became closely connected to their social image and their self-image. [Anita, primary school teacher of English]

A similar view was presented by Kristina from the first focus group, who confirms that English has become the language of their free time:

As we got older, it became more and more important. It somehow went hand in hand with the development of the TV, the Internet, later also smartphones. And when you hit puberty, you started looking for idols and people to look up to and they were all singers and actors, mostly Americans and the English, and it's normal that also English became more and more important. [Kristina, focus group 1]

When asked about what her motive for learning English was, she replied:

Well, first I wanted to get good grades in the matura because the faculty I wanted to study at had rather strict entry requirements. And the second reason: I was a teenager and wanted to go live somewhere abroad. [Kristina, focus group 1]

In the same focus group Manca added another role English played in their lives; when talking about why it was important to speak English, she focused on the social aspect:

When you go somewhere and meet a new friend, it is important that you can communicate at least a little bit, so that you can at least make contact with them and then keep in touch when you get home. And, of course, you use English, which is a common language, because if you come from different countries where the languages are very different, you use English and not their or our language. I think that knowing you might meet someone and get a chance to visit them is very motivating. And then again, you have to be able to get the message across ... [Manca, focus group 1]

Another student from the first focus group shared her experience which showed how important foreign languages (Italian, Croatian) were in her childhood and how English slowly took over as the main language one is supposed to know: 
When I was a child, we learnt Italian and when I went to Italy and asked something in Italian, I felt accepted because I could communicate. Or in summer, when we went on holidays to Croatia, we children also picked up some Croatian and when we went to the shop or to get some icecream, we could ask for things in Croatian and again we felt accepted. And when you get older, you start travelling and then your poor English becomes noticeable. Then you get that feeling: 'Well, I can't really go anywhere as I can't speak their language and I also can't speak English and I just won't be able to get by.' We could see how English developed in all the countries and everyone started speaking English and if you wanted to go somewhere, you just had to learn it if you wanted at least to get the message across. [Metka, focus group 1]

Simon, a teacher of English in primary school observed significant differences in the status of English among his pupils compared to other foreign languages, particularly Italian in the Primorska region:

In our region it is interesting how they absolutely don't consider it 'cool' to speak Italian. Some of them speak English even before they enter school, because they're motivated or because their parents motivate them. But in the coastal region it's definitely 'not-cool' if you speak Italian, even though it is the language of the environment ... well, the official language, at least. Other languages of the environment are also Serbian, Albanian ... but English is simply 'cool' and their world is full of English. The children prefer English computer games to Italian, and they don't watch Italian programmes on TV but English ones. [Simon, primary school teacher of English]

Drawing on the experiences of Metka and Simon, we could conclude that in the past Italian played a more important role in young people's lives than it does today. It is clear that English has taken over, which was also confirmed by Anita:

English is very much present in their out-of-school activities, for instance the Internet and films, whereas Italian in our region is losing this role and has not only become less popular among teenagers of, let's say, the last three years of primary school, but there has been a significant decrease in the level of knowledge. And Italian definitely doesn't have that influence ... in the sense of their identity. [Anita, primary school teacher of English] 
A very illustrative observation on how important English is in the lives of young people in Slovenia was offered by Karmen, a secondary school teacher of English:

Everybody thinks that English is extremely important, and I have noticed recently how they perceive this usefulness in terms of finding employment. It is crucial what you put in your CV. Language proficiency comes first and it is no longer enough if you say you speak a language, but you must specify how well you can speak it. Your employer will want to know whether your proficiency level is $C_{1}$ or $C_{2}$, maybe. And the students are aware of this and are seeking quality and in the end, they also accept the fact that I am strict and demanding. [Karmen, secondary school teacher of English]

The prospect of better employment was also one of the reasons for learning English mentioned by Manca from the first focus group:

When you get older, you start thinking about getting a job, and very often it is required that you speak a foreign language so English is definitely an option here. And, yes, if you don't speak English, you are somehow ..., well ... [Manca, focus group 1]

Karmen added another thought about the significance of English and the effects of (not) speaking it:

Now I'm also tutoring the parents, who have to learn English in order to keep their jobs. At the moment, I'm working with a 48-year-old woman, who is struggling with English. She's learning English for finance and accounting and the vocabulary is simply overwhelming for someone who is still trying to grasp the basics of English. But she is forced to learn if she wants to keep her employment. And this is the thing that the children detect, these situations at home. And when you ask them if English is important, you can hear them reciting their parents: 'We live in a world where English is of utmost importance!' [Karmen, secondary school teacher of English]

The results presented above indicate how students perceive English as extremely important in relation to their social lives and possible future employment. As a result, they are highly motivated for learning English. However, we 
have found that this perceived importance of English can also have a negative effect on individuals, as they exhibit high levels of foreign language anxiety resulting from either internal or external pressure of having to reach high levels of English language proficiency. Our research (Žefran 2017) has shown that the respondents demonstrate relatively high levels of foreign language anxiety with more than 37 per cent of the students experiencing strong or very strong levels of FL anxiety.

When asked to comment on the high levels of foreign language anxiety when learning English, Anita commented:

Because they are so much exposed to English outside of the classroom, the differences in their knowledge tend to grow, especially in terms of their vocabulary and communicative skills, and when they become aware of that, it can be a problem for some of them. And in my experience, English has become one of the main languages of the young people's free time and it suddenly became closely connected to their social image and their self-image. It seems that if you're not good at English you're in a way much more exposed than if you're not good at for example Chemistry or Mathematics. That's my perception. [Anita, primary school teacher of English]

According to Anita's experience, English is no longer just a school subject but has become part of young people's identities, which can put children under considerable pressure. If a general belief among teenagers is that knowing English makes them important, then those who cannot speak it well, can feel inferior and as a result experience anxiety.

In secondary school, Karmen observed that anxiety emerges when students realise that English is a basic requirement if they want to achieve something important in their lives:

Yes, I think it puts them under pressure. When they see they can get a job because of this. Or even at the university, for example, if they want to study medicine and realise that everything is in English and they start asking themselves: 'How will I manage if everything is in English?' [Karmen, secondary school teacher]

The same view is shared by another secondary school teacher who, when asked why foreign language anxiety is such a problem among students, replied: 
Yes, I think it is. I believe everyone is aware of just how important English is. [Tamara, secondary school teacher]

Mark, a participant of our second focus group interview, also confirmed that English is perceived to be extremely important:

Well, everyone thought that English is a must ... that you absolutely have to know English. [Mark, focus group 2]

Anita again compared English to Italian and in her experience, English is the preferred language of her pupils, which is, as she points out, again a source of anxiety in some learners:

English is very much present in their out-of-school activities, for instance the Internet and films, whereas Italian in our region is losing this role and has not only become less popular among teenagers of, let's say, the last three years of primary school, but there has been a significant decrease in the level of knowledge. And Italian definitely doesn't have that influence ... in the sense of their identity. This is probably why they feel more pressured to learn English and not so much Italian. [Anita, primary school teacher]

Based on the above-mentioned reports of teachers and students alike, we can conclude that the perceived importance of English among young people in Slovenia can result in the emergence of foreign language anxiety. However, in some cases, it might have just the opposite effect. This was explained by one of our respondents, a primary school teacher, who believes that this constant exposure to English can in fact decrease learners' anxiety as it offers extra support in language learning:

This is just my speculation, as I don't have any direct experience, but the learners who also learn a second foreign language tell me that they don't feel as anxious learning English compared to other languages because they are more exposed to English in so many other areas - they watch cartoons and films which is a kind of scaffold for their learning and because of that they're less worried about English than about other languages where this exposure is not present. [Maja, primary school teacher of English]

Maja's view adds evidence of the complexity of the relationship between 
learners' perceptions of English and their FL anxiety and calls for a more indepth research of the phenomenon.

As we have seen above, the results revealed complex relationships between students' perceptions of English and their learning motivation and foreign language anxiety. On one hand, they are extremely motivated to learn English as they perceive English as a language of power, whereas on the other hand, this same perception can lead to foreign language anxiety, as they feel pressured to learn and speak English well.

\section{Conclusion}

The results of the study presented in this paper suggest that students' perceptions of English have a considerable effect on their motivation and foreign language anxiety. According to several respondents, English has become an essential language of young people's social lives and their free time:

When you go somewhere and meet a new friend, it is important that you can communicate at least a little bit, [...] And, of course, you use English ... [Manca, focus group 1]

[...] English is simply 'cool,' and their world is full of English. [Simon, primary school teacher]

[...] when you hit puberty, you started looking for idols and people to look up to and they were all singers and actors, mostly Americans and the English, and it's normal that also English became more and more important. [Kristina, focus group 1]

These findings are in line with Lamb $(2004,5)$ who argues that:

In the minds of learners, English may [...] be associated [...] with a spreading international culture incorporating (inter alia) business, technological innovation, consumer values, democracy, world travel, and the multifarious icons of fashion, sport and music.

Participants in the study, students and teachers alike, reported that high motivation for learning English results from the perceived importance of the English language, which is also claimed by Ryan (2006), whose paper explains the relationship between learning motivation and the role of English, 'the unquestioned language of globalisation,' which the learners perceive as a means to develop a new (global) identity. 
In addition, as our research has shown, the perceived status of English is one of the possible sources of foreign language anxiety among students. However, the relationship between the perceived importance of the English language and foreign language anxiety is far from simple. The existing research in the field of FL anxiety shows that the major sources of anxiety are associated with some personal factors, such as self-esteem, attitudes and beliefs (Maclntyre and Gardner 1991; Oxford 1999), as well as situational factors, like classroom procedures, teacher-learner interactions, testing, and peer reactions (Gregersen 2003; Horwitz, Horwitz, and Cope 1986; Price 1991; Horwitz and Young 1991; Young 2001; Žefran 2017). We would like to argue that within the scope of attitudes towards foreign languages and learner beliefs, the perceived importance of English plays a significant part. Research done on motivational orientations towards foreign language learning also indicates that students often exhibit high levels of anxiety, but at the same time also demonstrate relatively high learning motivation (Chambers 1998; Noels et al. 2000; Dörnyei 2006). Similar findings have been offered by our study, with the majority of respondents being highly motivated for learning English but at the same time many of them exhibiting considerable levels of foreign language anxiety. The implications in this paper call for a more in-depth study of the relationship between the perceived importance of English and motivation as well as foreign language anxiety and encourage us to consider how greater understanding of this relationship can contribute to foreign language learning success.

\section{References}

Apple, Matthew T., Dexter DaSilva, and Terry Fellner, eds. 2013. Language Learning Motivation in Japan. Bristol: Multilingual Matters.

Bratož, Silva, and Mojca Žefran. 2012. 'English as an Added Value in Academic Settings.' In Akademskijeziki včasu globalizacije, edited by Sonja Starc, 20518. Koper: Annales.

Carroll, John B., and Stanley Sapon. 1959. The Modern Languages Aptitude Test. San Antonio, TX: Psychological Corporation.

Chambers, Gary N. 1998. 'Pupils' Perception of the Foreign Language Learning Experience.' Language Teaching Research 2 (3): 231-59.

Clément, Richard. 1980. 'Ethnicity, Contact and Communicative Competence in a Second Language.' In Language: Social Psychological Perspectives, edited by Howard Giles, Peter W. Robinson, and Philip M. Smith, 147-54. Oxford: Pergamon.

Crystal, David. 2012. English as a Global Language. Cambridge: Cambridge University Press. 
Csizer, Kata, and Michael Magid, eds. 2014. The Impact of Self-Concept on Language Learning. Bristol: Multilingual Matters.

Čeh, Živa. 2012. 'English as a Lingua Franca.' In Akademski jeziki v času globalizacije, edited by Sonja Starc, 195-204. Koper: Annales.

Deci, Edward L., and Richard M. Ryan. 1985. Intrinsic Motivation and Self-Determination in Human Behaviour. New York: Plenum.

- 2009. 'Self-Determination Theory: A Consideration of Human Motivational Universals.' In The Cambridge Handbook of Personality Psychology, edited by Philip J. Corr and Gerald Matthews, 441-56. New York: Cambridge University Press.

Dörnyei, Zoltán. 2005. The Psychology of the Language Learner: Individual Differences in Second Language Acquisition. Mahwah, NJ: Lawrence Erlbaum and Associates.

- 2006. Researching L2 motivation: Towards Combined Quantitative-Qualitative Paradigms. Nottingham: University of Nottingham.

Dörnyei, Zoltán, Peter Maclntyre, and Alastair Henry, eds. 2015. Motivational Dynamics in Language Learning. Bristol: Multilingual Matters.

Dörnyei, Zoltán, and Istvan Ottó. 1998. 'Motivation in Action: A Process Model of L2 Motivation.' In Working Papers in Applied Linguistics 4:43-69.

Dörnyei, Zoltán, and Stephen Ryan. 2015. The Psychology of the Language Learner Revisited. New York: Routledge.

Dörnyei, Zoltán, and Richard Schmidt, eds. 2001. Motivation and Second Language Acquisition. Honolulu, HI: University of Hawaii Press.

Dörnyei, Zoltán, and Ema Ushioda, eds. 2009. Motivation, Language Identity and the L2 Self. Bristol: Multilingual Matters.

Ellis, Nick C., and Diane Larsen-Freeman. 2006. 'Language Emergence: Implications for Applied Linguistics; Introduction to the Special Issue.' Applied Linguistics 27 (4): 558-89.

Eurydice. 2017. Key Data on Teaching Languages at School in Europe. Luxembourg: Publications Office of the European Union.

Gardner, Robert C. 1985. Social Psychology of Second Language Learning: The Role of Attitudes and Motivation. London: Edward Arnold.

—. 2004. 'Attitude/Motivation Test Battery.' http://publish.uwo.ca/ gardner/docs/englishamtb.pdf

- 2006. 'Motivation and Second Language Acquisition.' Manuscript.

Gardner, Robert C., and Richard Clément. 1990. 'Social Psychological Perspectives on Second Language Acquisition.' In Handbook of Language and Social Psychology, edited by Howard Giles and W. Peter Robinson, 495-517. Chichester: Wiley.

Gardner, Robert C., and Wallace E. Lambert. 1972. Attitudes and Motivation in Second-Language Learning. Rowley, MA: Newbury House.

Giles, Howard, and Jane L. Byrne. 1982. 'An Intergroup Approach to Second Lan- 
guage Acquisition.' Journal of Multilingual and Multicultural Development 3:17-40.

Gregersen, Tammy. 2003. 'To Err Is Human: A Reminder to Teachers of LanguageAnxious Students.' Foreign Language Annals 36 (1): 25-32.

Gregersen, Tammy, and Peter D. Maclntyre. 2014. Capitalizing on Language Learners' Individuality: From Premise to Practice. Bristol: Multilingual Matters.

Horwitz, K. Elaine. 2001. 'Language Anxiety and Achievement.' Annual Review of Applied Linguistics 21:112-27.

Horwitz, K. Elaine, and Dolly J. Young, eds. 1991. Language Anxiety: From Theory and Research to Classroom Implications. Englewood Cliffs, NJ: Prentice Hall.

Horwitz, K. Elaine., Michael B. Horwitz, and Joann Cope. 1986. 'Foreign Language Classroom Anxiety.' The Modern Language Journal 70:125-32.

House, Juliane. 2003. 'English as a Lingua Franca: A Threat to Multilingualism?' Journal of Sociolinguistics 7 (4): 556-78.

Jenkins, Jenny. 2007. English as a Lingua Franca: Attitude and Identity. Oxford: Oxford University Press.

Juriševič, Mojca, and Karmen Pižorn. 2013. 'Young Foreign Language Learners' Motivation: A Slovenian Experience.' Porta linguarum 19:179-98.

Kachru, Braj B. 1992. The Other Tongue: English across Cultures. Champain, IL: University of Illinois Press.

Lamb, Martin. 2004. 'Integrative Motivation in a Globalizing World.' System 32 (1):3-19.

Lasagabaster David, Aintzane Doiz, and Juan Manuel Sierra, eds. 2014. Motivation and Second Language Learning: New Theoretical Insights and the Interaction with the CLIL Approach. Amsterdam: John Benjamins.

Maclntyre, Peter, and Robert Gardner. 1991. 'Language Anxiety: Its Relationship to Other Anxieties and to Processing in Native and Second Languages.' Language Learning 41 (4): 513-34.

Matsuda, Sae, and Peter Gobel. 2004. 'Anxiety and Predictors of Performance in the Foreign Language Classroom.' System 32 (1): 21-36.

Mihaljević Djigunović, Jelena. 2012. 'Attitudes and Motivation in Early Foreign Language Learning.' CEPS Journal 2 (3): 55-74.

Murray, Garold, Xuesong Gao, and Terry Lamb, eds. 2011. Identity, Motivation and Autonomy in Language Learning. Bristol: Multilingual Matters.

Noels, Kimberly A., Luc G. Pelletier, Richard Clement, and Robert J. Vallerand. 2000. 'Why Are You Learning a Second Language? Motivational Orientations and Self-Determination Theory.' Language Learning 50 (1): 57-85.

Oxford, Rebecca. 1999. 'Anxiety and the Language Learner: New Insights.' In Affect in Language Learning, edited by Jane Arnold, 58-67. Cambridge: Cambridge University Press.

Pennycook, Alastair. 1999. 'Pedagogical Implications of Different Frameworks 
for Understanding the Global Spread of English.' In Teaching and Learning English as a Global Language - Native and Non-Native Perspectives, edited by Claus Guntzmann, 147-56. Tübingen: Stauffenberg-Verlag.

Price, M. L. 1991. 'The Subjective Experience of Foreign Language Anxiety: Interviews with Highly Anxious Students.' In Language Learning Anxiety: From Theory and Research to Classroom Implications, edited by Elaine Horwitz and Dolly Young, 101-8. Englewood Cliffs, NJ: Prentice Hall.

Ryan, Stephen. 2006. 'Language Learning Motivation within the Context of Globalisation: An L2 Self within an Imagined Global Community.' Critical Inquiry in Language Studies 3 (1): 23-45.

Schumann, John H. 1978. The Pidginization Process: A Model for Second Language Acquisition. Rowley, MA: Newbury House.

- 1986. 'Research on the Acculturation Model for Second Language Acquisition.' Journal of Multilingual and Multicultural Development 7 (5): 37992.

Scovel, Thomas. 1991. 'The Effect of Affect on Foreign Language Learning: A Review of the Anxiety Research.' In Language Anxiety: From Theory and Research to Classroom Implications, edited by Elaine K. Horowitz and Dolly J. Young, 15-24. Englewood Cliffs, NJ: Prentice Hall.

Seidlhofer, Barbara. 2005. 'English as a Lingua Franca.' ELT Journal 59 (4):339-41. Ushioda, Ema. 2009. 'A Person-in-Context Relational View of Emergent Motivation, Self and Identity.' In Motivation, Language Identity and the L2 Self, edited by Zoltán Dörnyei and Ema Ushioda, 215-28. Bristol: Multilingual Matters.

_ - ed. 2013. International Perspectives on Motivation: Language Learning and Professional Challenges. Basingstoke: Palgrave Macmillan.

Verma, Meenakshi. 2008. 'Learner's Attitude and Its Impact on Language Learning.' http://147.8.145.43./clear/conferenceo8/doc/handouts/VERMA Meenakshi H_handout.pdf

Vytal, Katherine, Brian Cornwell, Nicole Arkin, and Christian Grillon. 2012. 'Describing the Interplay between Anxiety and Cognition: From Impaired Performance under Low Cognitive Load to Reduced Anxiety under High Load.' Psychophysiology 49 (6): 842-52.

Young, J. Dolly. 1991. 'Creating a Low-Anxiety Classroom Environment: What Does Language Anxiety Research Suggest?' The Modern Language Journal $75(4): 426-43$.

Žefran, Mojca. 2017. 'Vpliv individualno-situacijskih dejavnikov na učenje tujega jezika.' PhD dissertation, University of Primorska.

Žefran, Mojca, and Majda Cencič. 2013. 'Tesnobnost pri pouku angleškega jezika.' Annales: Series historia et sociologia 23 (2): 355-64. 